Revue de l'Institut des langues et cultures

d'Europe, Amérique, Afrique, Asie et Australie

$31 \mid 2018$

Récits fictionnels et non fictionnels liés à des communautés professionnelles et à des groupes spécialisés

\title{
Nurturing the Wealth Beneath Our Feet or Trampling Sacred Grounds? Blog Narratives on Fossil Fuel Development in New Zealand 2010- 2016
}

Faire fructifier la richesse sous nos pieds ou piétiner des terres sacrées? Récits de blogs sur le développement des énergies fossiles en Nouvelle-Zélande 2010-2016

\section{Camille Biros}

\section{OpenEdition}

\section{Journals}

Electronic version

URL: http://journals.openedition.org/ilcea/4678

DOI: $10.4000 /$ ilcea.4678

ISSN: 2101-0609

\section{Publisher}

UGA Éditions/Université Grenoble Alpes

Printed version

ISBN: 978-2-37747-043-3

ISSN: $1639-6073$

\section{Electronic reference}

Camille Biros, « Nurturing the Wealth Beneath Our Feet or Trampling Sacred Grounds? Blog Narratives on Fossil Fuel Development in New Zealand 2010-2016», ILCEA [Online], 31 | 2018, Online since 06 March 2018, connection on 21 April 2019. URL : http://journals.openedition.org/ilcea/4678; DOI : 10.4000/ilcea.4678

This text was automatically generated on 21 April 2019.

(C) ILCEA 


\section{Nurturing the Wealth Beneath Our Feet or Trampling Sacred Grounds? Blog Narratives on Fossil Fuel Development in New Zealand 2010- 2016}

Faire fructifier la richesse sous nos pieds ou piétiner des terres sacrées? Récits de blogs sur le développement des énergies fossiles en Nouvelle-Zélande 2010-2016

\section{Camille Biros}

\section{Introduction}

1 Moving beyond extractive industries towards more environmental forms of energy production could require a shift in the dominant narrative of "extractive cultural production" (MacDonald, 2013: 4). Narration can therefore be seen as a tool to shape the low-carbon futures we strive to build. In New Zealand today, narratives about energy are all the more important as New Zealand could be on the verge of the major development of unconventional fossil fuels. Since John Key's election in 2008, several policies encouraging exploration and exploitation have been launched. This has not been without generating opposition from concerned environmental and local groups. The heated debate is visible in blogs written since 2008 in New Zealand.

2 To give a broad definition of this discursive genre, "weblogs are webpages which are regularly updated, with the most recent material appearing at the top, usually datestamped" (Hopkins \& Matheson, 2005: 94). The interest for this type of genre is explained by its accessibility and openness to different types of authors and readers, reflecting a large diversity of points of view. One of the hypotheses we test is whether specific 
narrative forms are being reflected in this genre. To do so, we begin by presenting the context in which the blogs were written. We then analyse the blogs to determine the types of narratives being told regarding conventional sources of energy. Finally, we question the characteristics of the blog as a discursive genre and reflect on its role in the debate over petroleum development.

\section{Setting the Stage: Fractures in New Zealanders' Perceptions of Fossil Fuel Development}

\subsection{Fossil Fuel Development in New Zealand}

3 The case of New Zealand cannot be considered in isolation from the international context. The development of new extractive practices has recently led to a massive change in energy production patterns, in particular in the United-States (Loomis, 2017: 13). Although there are many risks associated to water pollution, toxic emissions and even seismic reactions, the argument of energy autonomy has been used to justify these practices and thwart opposition. The oil and gas industry has been very active in promoting these new sources and minimizing the risks. A trend of mergers and acquisitions has been observed in this industry (Reddy \& Xie, 2017: 979), leading to the development of highly powerful industries that communicate extensively on issues linked to the extraction of unconventional fossil fuels such as oil shale, oil sands, extra heavy oil, and natural bitumen.

In New Zealand, when John Key became Prime Minister in 2008, he proposed a Business Growth Agenda calling for a major expansion of the oil and gas industry. Land was removed from under the protected areas scheme and the 2012 Petroleum Action Plan established a new block offer system for exploration permits, i.e. a collective process through which all industries can apply, opening land on which the government has already organised consultation of local stakeholders. Through these block offers, the open aim of the New Zealand government is to attract companies and stimulate investment ${ }^{1}$. The government also provides companies with an exploration database, a collection of free geoscience exploration data, and reports to facilitate prospecting.

\subsection{Environmentalist Reactions}

5 Like in other countries from the English diaspora (United-States, Canada, Australia), environmentalism in New Zealand is strongly influenced by a conservationist view of nature (Dunlap, 1999: 308). This has led to a strong focus on preserving native plants and species through the creation of areas where human impact is as low as possible. Consequently, John Key's government's proposal to open national park estates to mining led to a 50,000-people march through Auckland on $5^{\text {th }}$ May 2010. The next strong mobilisation that brought together many environmentalist groups and local Maori was the protest in March 2011 against the government granting the Brazilian energy firm Petrobras a permit to explore oil drilling off the East Coast of the North Island. In October 2011, a container ship named the Rena spilt oil near Tauranga on the East Coast of the North Island, where most exploration permits were granted. This also produced strong anti-oil sentiment in the local population. 


\subsection{Maori Stakeholders}

6 Maori do not relate to the concept of wilderness. According to their beliefs, nature should not be preserved as untouched by humans. There is no distinction between the natural and the human world in Maori spirituality as natural elements represent ancestors and each Iwi or Hapu (which could tentatively be translated by "tribes" and "sub-tribes" respectively) entertains strong links to one or several natural elements that define their identity. Maori have spiritual rituals surrounding the natural environment which can include the extraction of precious natural resources. Preservationist policies are often viewed with hostility amongst this population as they limit their access to natural resources. These conflicts are also linked to issues of identity. Their bond to the land distinguishes them from European settlers and their descendants and creates reservations about teaming up with them, even if it is to fight environmental destruction. Maori however have an important role to play in development projects in New Zealand and their position can be determining for local policies. Iwi and Hapu have gained legal recognition thanks to the determining role of the Tribunal of Waitangi, which uses the Treaty of Waitangi, signed between the Queen and a number of Iwi heads in 1840, to reestablish Maori customary rights over land. As such, they need to be actively consulted if a development project concerns land determined as linked to their Hapu. This means Maori consultation is a necessary step to any exploration permit grant. Companies need to be aware of this and the government consequently provides support for consultation of Iwi groups namely through the publication of drafts of consultation protocols for companies to follow. However, they are sometimes accused of not following the protocols in a very ethical manner. According to Loomis (2017: 14), there have been complaints about Maori individuals receiving money to support development projects. Because they have a distinct power as compared to other regional stakeholders in local politics, Maori groups are definitely part of the debate and companies tend to lobby them. Environmental groups mounting opposition campaigns also tend to approach them to gain credentials when fighting a development project (O'Brien, 2013: 222). In this light, it is easy to understand why Maori have distinct voices in the debates over oil development in New Zealand.

\section{Differentiated Blog Narratives on Fossil Fuel Development}

\subsection{Building the Corpus}

7 Our interest for blogs comes from their accessibility and openness to different types of authors. This was confirmed by finding that the major stakeholders concerning oil development in New Zealand had all chosen blogs as a means of communication. The primary stakeholder to consider is the oil industry itself. TAG Oil is a Canadian-based oil and gas industry that is at the forefront of oil exploration in Australia and New Zealand. It has been writing a blog named Tag Oil Blog since September $2010^{2}$. The TAG Oil corpus is composed of the 23 posts written about New Zealand between September 2010 and September 2016. It contains 6,392 words and also includes photos and videos. 
The second important voice is that of the National Party, the political party of the Prime Minister, John Key. As previously mentioned, it has played a major role since 2008 in making New Zealand an attractive place for fossil fuel industries to invest in. There is no official blog but David Farrar is a blogger who has held several roles in the party and was in parliament for eight years. As such, his voice can be considered as representative of the National Party's position. The blog he writes is called the Kiwi Blog (KB) and it is one of the most widely read in New Zealand. The corpus of 10,834 words includes the 35 posts written about oil development between May 2010 and November 2016.

The third important voice is that of environmentalist opposition. One group that is very active against oil development in New Zealand is Climate Justice Taranaki (Loomis, 2017: 203). Although it mostly works at a local level in the region of Taranaki, it takes interest in fossil fuel development in New Zealand in general and is largely quoted. It holds a blog entitled Climate Justice Taranaki Blog (CJT) ${ }^{3}$ and the corpus is composed of 25 posts $\left(10,742\right.$ words) about fossil fuel development written between $4^{\text {th }}$ June 2014 and $22^{\text {nd }}$ September 2016.

10 The fourth and final essential voice to consider is that of Maori blogs. The Maori blogs considered did not have many posts on the topic so two were selected to gather more posts. The Non Plastic Maori (NPM) is a blog written by a young woman who protests against the petroleum industry by adopting a life style without plastic ${ }^{4}$. Although most of the posts are devoted to explaining how this affects her life and the difficulties she encounters, a number of posts refer to fossil fuel development in New Zealand. Five posts, written between $26^{\text {th }}$ January 2014 and $7^{\text {th }}$ August 2016 and including 4,855 words, were selected from this blog. The second blog is entitled Mars 2 Earth (M2E) ${ }^{5}$. It also is written by a Maori who opposes fossil fuel development and rejects National Party politics. Twelve posts written between $11^{\text {th }}$ February 2010 and $4^{\text {th }}$ May $2013^{6}$ on fossil fuel development were selected from this blog (6,608 words).

\subsection{Similar Events, Differing Plots}

11 The events presented in the first part of this article are those mentioned in the different blogs, written over a similar time period and dealing with the same issues. However, the story differs. The events are not organised in the same way and are not given the same meaning. To explain this concept of "story" as used here, we refer to the definition given by French linguist and narratology theorist Jean-Michel Adam for whom a story is composed of five parts: an exposition, a conflict (Noeud), a reaction, a resolution and a conclusion ${ }^{7}$.This structure enables the events to be built meaningfully (Adam, 2011: 70). Each blog we consider here builds the events into different narrative structures that give them very different meanings.

Table 1. - Narrative Sequence in Blogs

\begin{tabular}{|l|l|l|l|l|l|}
\hline Blog & Exposition & Conflict & Reaction & Resolution & Conclusion \\
\hline TAG & $\begin{array}{l}\text { NZ needs } \\
\text { money }\end{array}$ & $\begin{array}{l}\text { Discovery of } \\
\text { fossil fuel } \\
\text { potential }\end{array}$ & $\begin{array}{l}\text { Brave efficient } \\
\text { men get to work }\end{array}$ & $\begin{array}{l}\text { Obstacles (low oil } \\
\text { prices, } \\
\text { opposition) } \\
\text { overcome }\end{array}$ & $\begin{array}{l}\text { Aim: } \\
\text { wealthier New } \\
\text { Zealand }\end{array}$ \\
\hline
\end{tabular}




\begin{tabular}{|c|c|c|c|c|c|}
\hline KB & \begin{tabular}{|ll} 
NZ & needs \\
money &
\end{tabular} & 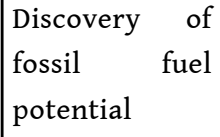 & $\begin{array}{l}\text { Great work of } \\
\text { industry and } \\
\text { government }\end{array}$ & $\begin{array}{l}\text { Obstacles (mainly } \\
\text { opposition) but } \\
\text { results expected }\end{array}$ & $\begin{array}{l}\text { Aim: a } \\
\text { wealthier } \\
\text { Zealand }\end{array}$ \\
\hline CJT & $\begin{array}{l}\text { Fossil fuel } \\
\text { responsible for } \\
\text { climate change }\end{array}$ & $\begin{array}{l}\text { Fossil fuel } \\
\text { industry } \\
\text { dangerous } \\
\text { threat }\end{array}$ & Activism needed & $\begin{array}{l}\text { Hope to oppose } \\
\text { development }\end{array}$ & $\begin{array}{l}\text { Aim: a cleaner } \\
\text { New Zealand }\end{array}$ \\
\hline $\begin{array}{l}\text { NPM } \\
\text { and } \\
\text { M2E }\end{array}$ & $\begin{array}{l}\text { Maori } \\
\text { oppressed by } \\
\text { settlers }\end{array}$ & $\begin{array}{l}\text { Fossil fuel } \\
\text { industry } \\
\text { associated } \\
\text { with settlers }\end{array}$ & $\begin{array}{lr}\text { Activism } & \text { and } \\
\text { connection } & \text { to } \\
\text { Maori roots } \\
\text { needed }\end{array}$ & $\begin{array}{l}\text { Hope to oppose } \\
\text { development }\end{array}$ & $\begin{array}{l}\text { Aim: a cleaner } \\
\text { Maori New } \\
\text { Zealand }\end{array}$ \\
\hline
\end{tabular}

The same characters appear in these narratives: the oil industry, the government, environmentalist opposition, Maori groups and a fifth character, that we haven't mentioned so far, "the people", a notion which differs greatly from one blog to another. We are now going to look at the differences in narrative sequences by focusing on the different characters in each blog and their contrasting roles in the narrative.

\subsection{The Fossil Fuel Industry}

13 According to the TAG Oil Blog, the fossil fuel industry is a major and highly active character. The list of the positive aspects attributed to this industry by TAG Oil is long. The first impression that stands out is that it is very active: "we have a lot of irons in the fire" (07/09/10), "no time to rest on our laurels, it's time to get busy" (05/04/11), to quote just a few examples. Another notion relates to its size highlighted by the use of superlatives, "the most extensive" (09/02/12) and figures, "750 barrels a day, and that's just the beginning" (09/05/11). Other attributes are its success, its wealth, its pride and its courage. It even goes so far as to consider there is beauty in the oil industry with this romantic caption of an oil rig photo: "the rig is a thing of beauty against heavy grey clouds" (05/04/11). Similarly, the view presented on Kiwi Blog is positive, although the description is a little less eulogistic. It is presented as advantageous from an economic point of view (09/01/14). It is also presented as clean, "Fracking good for climate change" (26/06/12), and relatively safe, "[b]oth the energy sector and governmental environment watchdogs agree the industry is far safer now than it was even three years ago" (02/12/13).

On the other hand, the three other blogs offer negative representations of the oil industry. On the Climate Justice Taranaki (CJT) blog it is presented as "literally a dirty industry" (04/06/14) and is said to represent a "cowboy behaviour" (25/20/14). On NonPlastic Maori (NPM) it is presented as exploitative. Its power over the government leads this blogger to coin the term "corporatocracy" (07/08/16). She also sees it as dirty, with examples of oil spills and figures about how much it contributes to climate change. The words used to deprecate the industry are even stronger in Mars 2 Earth (M2E) where it is described in terms of "money-hungry exploiters" (04/05/13), "predators" (02/05/13), "corporate animal" (02/05/13) or "the worst of humanity" (02/05/13). 


\subsection{The Government}

15 Although an important stakeholder, the government is not mentioned at all in the TAG Oil blog and hardly so in the KB one. Inversely, the three other blogs are very critical of the government because they see it as playing the game of the fossil fuel industry. CJT considers the government is irresponsible in its call for the development of fossil fuels: "total madness" (22/03/16), "ludicrous" (22/09/16). It presents the government as "working for foreign corporations rather than for New Zealanders" (18/02/15). It shows itself in clear opposition to the type of policies voted by John Key's government: "there is freedom to be had beyond neo-liberalism" (22/09/16). The NPM sees the government as a coloniser and finds that there is a coherence between their willingness to help the fossil fuel industry and the role the government has played throughout the history of New Zealand: "the state use of police and armed forces to clear indigenous people away from natural resources in order to facilitate natural resource exploitation and corporate expansion is not new" (07/08/16). The role of the government is also highly criticised by M2E: "the government has opened the gate for the predators" (24/01/12). It also questions the legitimacy of the government's action: "It is our right under Te Tiriti o Waitangi to say NO to drilling and mining along the East Coast" (10/03/11).

\subsection{Environmental Opposition}

16 There is no mention of environmental opposition in the TAG Oil blog. However it is a theme that is widely covered in $\mathrm{KB}$ who presents environmentalists as irrational: "opponents do tend to have a near-religious belief that any use of Earth's natural resources is spiritually wrong, and must be opposed" (16/01/14). Their opposition is synonymous with poverty according to him: "that is a route to poverty" (23/06/12).

17 The three other blogs present the work of opponents to the fossil fuel industry as essential. CJT is a major actor in the organisation of opposition with many posts on the blog about organising information meetings against the government's plans and invitations to sign petitions. It often quotes scientific reports and develops the idea that all their assertions regarding the polluting capacity of the industry are based on trustworthy sources: "peer-reviewed scientific studies" (21/06/16). They also show that they are part of a global movement of opposition rather than just an isolated New Zealand local group: "we are energised by the global climate justice movement" $(22 / 03 / 16)$. In the NPM, the main method advocated to oppose the fossil fuel industry is boycotting their products, in particular through living without plastics. However, other active opponents to fossil fuel expansion are also quoted, namely Climate Justice Taranaki. M2E also views opponents to fossil fuel development in a positive light. He uses the first person pronoun "we" to refer to them, showing that he includes himself in the movement of opposition: "it is our right" (10/03/11), "we can stop them" (24/01/12), "we will stop them" (03/05/11).

\subsection{Maori}

18 TAG Oil does not mention Maori. In the KB, we find only one occurrence. It recounts how local Maori groups team up with environmental opposition to fossil fuel development (23/06/12). CJT mentions Maori groups twice, in very different contexts, which testify to 
the ambiguous relations between environmentalists and Maori people. First, in a $14^{\text {th }}$ July 2014 post it mentions the spiritual value of the Maui Dolphin for Maori tribes, advancing spiritual values as an argument in favour of the protection of an area in which this dolphin lives. The other example is a $27^{\text {th }}$ August 2015 post which reports that Stat Oil is having secret meetings with Iwi groups, thus implying that Stat Oil may be manipulating Iwi groups to persuade them to back fossil fuel development. This lack of transparency is criticised. In this blog, as in the previous ones, the representation given of Maori people is from the outside.

This is far from being the case in the two other blogs where Maori voices are heard, and an important part of the discussion on the blog is devoted to what it means to have a Maori identity. In the NPM blog Maori are represented as victims of exploiters in the form of governments and industry. The violent past of the history of European settlement in New Zealand is evoked and the aggressiveness of the oil industry is seen as a continuation of this violent past, making Maori people vulnerable to attacks and rendering it impossible for them to live as they would like to live. The writer links her engagement against this type of industry to her spiritual beliefs and respect for her ancestors (07/08/16). Maori identity and indigenous rights in general are also an important theme in M2E, although the links between opposition to fossil fuel development and Maori identity are dealt with less explicitly in this particular blog.

\subsection{The People}

The notion of "people" varies according to the blog. In the TAG Oil blog, local people are an important stakeholder. The idea is to show that people living on the land around the area concerned with oil development have a positive relationship with the petroleum industry. They describe the farmers in particular and conclude "farming and oil exploration have co-existed in Taranaki for decades" (14/10/15). In a 30 ${ }^{\text {th }}$ September 2016 post, a video appears entitled "New Zealanders on Oil and Gas" and is presented as "a video of real people who work in the New Zealand oil and gas industry, giving a good indication of what it's like". They talk about their positive relation to the industry in simple words and portray it as safe, efficient, prosperous and a great opportunity for local people. The writer for the KB does not really mention "the people".

In CJT, the word "people" is used to refer to locals living around petroleum plants and thus most likely to be affected by them. The portrayal of their relation with the fossil fuel industry is radically opposed to the one presented in the TAG Oil blog. According to the CJT, the industry threatens "the safety and wellbeing of people and animals who reside and work in close proximity to oil and gas well sites" (22/01/16). It also refers to people around the world as being affected by climate change $(26 / 03 / 15 ; 09 / 12 / 14)$. In the NPM blog, the word "people" is used to refer to indigenous people and what the writer calls "Tagaloa ${ }^{8}$ people" $(07 / 08 / 14)$, thus highlighting the links between people from different Polynesian islands rather than the specificity of Maori. There is no reference to nonMaori New Zealanders. This distinction is less clear in the M2E blog. The author uses the pronoun "we" a lot and says he is talking for "the people" whom he opposes to those in power, as in the following extracts: "our water, our land and our people are under threat" (10/03/11), "puts power back into our people's hands" (21/10/11). The expression is used to refer to indigenous people but also to all victims of oppressive industries and governments. 
22 After this overview of the different stakeholders, their portrayal and the role they play in narratives surrounding oil development in the different blogs and the significant discrepancy between ways in which the events are referred to, we now move on to exploring to what extent the blog, as a genre, influences the way in which events are presented.

\section{The Specific Role of Blogs in Debates over Fossil Fuel Development}

\subsection{Can an "Open-ended, Branching, Hyperlinked, Cross-media, Participatory, Exploratory and Unpredictable" (Alexander \& Levine, 2008: 1) Discourse be a Story?}

Although blogs can be seen as a type of narrative in the sense that they start somewhere, present a series of events and have a chronological progression, whether they can be considered a story remains an open question. As mentioned in the introduction, one of the defining features of blogs is their sense of immediacy, as the most recently written post is the one that figures at the top of the blog, as pointed out by Herring et al. (2004: 2) when they say, "Blog authors tend to define blogs around their characteristic entriesposted-in-reverse-chronological-order format". For a blog to be widely followed and considered as active, updates should be frequent (daily or weekly). Although blogs tell a story, they do not seem to share the defining formal characteristics of a story. According to Revaz's work in narratology (2009), what defines a "story" from other forms of narrative sequences is that there is a shift between the opening situation and the closing situation and this shift gives meaning to the events. All the events build up towards the final conclusion. In blogs, events are told as they unfold and if they are given meaning, it is through commentaries, as they come. We were able to identify a story about fossil fuel development in each blog, by identifying the structure that builds the events together, even though this structure is underlying and not explicit.

Blogs are often seen as alternative sources of information that, unlike mainstream media, allow comments on events that aren't usually focused upon (Miller \& Shepherd, 2009: 278). However, other research on the issue appears to contradict this idea by showing that, far from offering a different perspective, weblogs tend to reinforce the importance of narratives found in the media (Hass, 2005: 389). All the blogs in the corpus feature several links to articles published in mainstream newspapers. The events presented follow these sources but are selected according to the focus of the blog. When we analyse the nature of the events presented in each blog, we are struck by the high degree of repetition. Each blog tends to comment on the same type of event and draw the same type of conclusion. A similar structure can be observed in the different posts of a same blog. Posts from the CJT blog provide a good illustration of this trend: in a $18^{\text {th }}$ September 2015 post entitled "Block the Offer", CJT starts by presenting the event which caused them to react, i.e. that the NZ government has started a "so-called consultation" of local populations on the block offer. This has led to a Greenpeace Campaign named "Block the Offer - Stop Deep Sea Oil" that CJT endorses. Comments are then made about what the granting of permits would mean for the Taranaki region. CJT draws a list of the different organisations opposing this and explains their reasons for doing so, mainly 
evoking the risk of climate change. It concludes by quoting President Obama defending renewable energies and saying that this is what the U.S. government should be encouraging. We find a similar structure pattern in a $22^{\text {nd }}$ March 2016 post entitled "Oil and Gas Block Offer Total Madness". Both posts are triggered by a government action and followed by commentaries on the negative consequences, locally and globally. The reference to the opposition is placed at the beginning in the first post, and at the end in the second one. Overall, if we look at the CJT blog, several posts follow this structure with a commentary on what the government or company is doing, a reflection on the consequences it could have both on the local and global scale, and a reference to the opposition to fossil fuel development and invitations to act against. The aim of the blog is quite clearly to spur opposition to this development and this is achieved through posts with repetitive content. The aim of the blog determines how the events are related and in what ideological frame they are integrated. In the TAG Oil blog, the events commented upon are linked to the development of the plants and the decisions taken about the company strategy. In the KB blog the posts start with quotes from neo-liberal politicians or activists to defend their ideas or from opponents to fossil fuel development to criticise their points of view. In the NPM, the posts on fossil fuel development are often linked to a post from another blog the author follows. M2E quotes activities by fossil fuel companies and new decisions taken by government to criticise them.

The question that naturally arises here is that if the content is so repetitive, how do these blogs maintain interest and readership? One answer could lie in the multimodality and interactivity that such genres offer. Could we be facing a genre in which the repetitive nature of the content is tuned down by the variety of ways of expressing them?

\subsection{Intermodality and Interactivity}

Second to its specific relation to time and its immediacy, another defining feature of the blog is its interactivity and intermodality. The decisive nature of the technology that enables the inclusion of different types of media and hyperlinks on these webpages is commented on by many weblog scholars (Miller \& Sheperd, 2009: 281; Herring et al., 2004: 11). To Andrew Sullivan, a famous American blogger, this feature makes for the depth of the reading you can have on blogs which offers "the ability to read the primary material instantly" (Sullivan, 2008). The best example of this feature probably lies in the CJT blog where hyperlinks are numerous and tend to back up most of the statements. To highlight this point we focus on a post where there are 15 hyperlinks in a text of 419 words, the contents of which are summed up in the following table.

Table 2. - Hyperlinks in the CJT 22 ${ }^{\text {nd }}$ September 2016 Blog Post

\begin{tabular}{|l|l|l|}
\hline Rank & Nature & Title of Website \\
\hline $\begin{array}{l}\text { Link } \\
1\end{array}$ & $\begin{array}{l}\text { Page about block offer on } \\
\text { government website. }\end{array}$ & Beehive Government NZ (www.beehive.govt.nz) \\
\hline $\begin{array}{l}\text { Link } \\
2\end{array}$ & $\begin{array}{l}\text { Official description of the Marine } \\
\text { Sanctuary. }\end{array}$ & $\begin{array}{l}\text { Department of Conservation website } \\
\text { www.doc.govt.nz) }\end{array}$ \\
\hline
\end{tabular}




\begin{tabular}{|c|c|c|}
\hline $\begin{array}{l}\text { Link } \\
3\end{array}$ & $\begin{array}{l}\text { Explanations about the Marine } \\
\text { Sanctuary being opened up for } \\
\text { exploration. }\end{array}$ & $\begin{array}{l}\text { New Zealand Petroleum and Minerals in Ministry of } \\
\text { Business, Innovation and Development } \\
\text { www.nzpam.govt.nz) }\end{array}$ \\
\hline $\begin{array}{l}\text { Link } \\
4\end{array}$ & $\begin{array}{l}\text { Another quotation from the same } \\
\text { website. }\end{array}$ & Ibid. \\
\hline $\begin{array}{l}\text { Link } \\
5\end{array}$ & $\begin{array}{l}\text { Blog about clean energy to } \\
\text { illustrate meaning of "climate- } \\
\text { survival technologies". }\end{array}$ & $\begin{array}{l}\text { Blog about "energy, climate and tech watching" ( } \\
\text { www.jeremyleggett.net) }\end{array}$ \\
\hline $\begin{array}{l}\text { Link } \\
6\end{array}$ & $\begin{array}{l}\text { An online PDF document written } \\
\text { by a Harvard Research Team on } \\
\text { "Developing Organic Flow } \\
\text { Batteries for Energy Storage". }\end{array}$ & $\begin{array}{l}\text { Hosted by Advanced Research Projects Agency - } \\
\text { Energy (ARPA-E) attached to the U.S. Department of } \\
\text { Energy (www.arpa-e.energy.gov) }\end{array}$ \\
\hline $\begin{array}{l}\text { Link } \\
7\end{array}$ & $\begin{array}{l}\text { Article entitled "Holy Grail of } \\
\text { Energy Policy in Sight as Battery } \\
\text { Technology Smashes the old } \\
\text { Order". }\end{array}$ & The Telegraph (www.telegraph.co.uk) \\
\hline $\begin{array}{l}\text { Link } \\
8\end{array}$ & 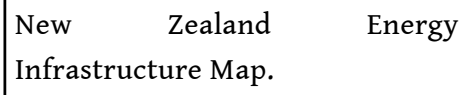 & Freeman Media (www.freemanmedia.co.nz) \\
\hline $\begin{array}{l}\text { Link } \\
9\end{array}$ & $\begin{array}{l}\text { Article entitled "Tiwai Smelter } \\
\text { deal signed between Meridian } \\
\text { Energy and NZAS". }\end{array}$ & The Stuff (www.stuff.co.nz) \\
\hline $\begin{array}{l}\text { Link } \\
10\end{array}$ & $\begin{array}{l}\text { Article "The Story of Gas in New } \\
\text { Zealand". }\end{array}$ & Gas Industry Company Ltd. (www.gasindustry.co.nz) \\
\hline $\begin{array}{l}\text { Link } \\
11\end{array}$ & $\begin{array}{l}\text { Proving that Methanol is being } \\
\text { manufactured in New Zealand } \\
\text { through reference to Methanol } \\
\text { industry website. }\end{array}$ & $\begin{array}{l}\text { Methanex website (www.methanex.com/location/ } \\
\text { new-zealand) }\end{array}$ \\
\hline $\begin{array}{l}\text { Link } \\
12\end{array}$ & $\begin{array}{l}\text { Taranaki Regional Council PDF } \\
\text { report on urea manufacturing } \\
\text { plant near Kapuni. }\end{array}$ & $\begin{array}{l}\text { Taranaki Regional Council Website (www.trc.govt.nz } \\
\text { ) }\end{array}$ \\
\hline $\begin{array}{l}\text { Link } \\
13\end{array}$ & $\begin{array}{l}\text { Blog post on "The Dark Side of } \\
\text { Renewable Energy". }\end{array}$ & $\begin{array}{l}\text { Blog called "The Wrong Kind of Green", ( } \\
\text { www.wrongkindofgreen.org) }\end{array}$ \\
\hline $\begin{array}{l}\text { Link } \\
14\end{array}$ & $\begin{array}{l}\text { Article contradicting a } \\
\text { declaration by Margaret } \\
\text { Thatcher saying there was "no } \\
\text { such thing as society". }\end{array}$ & The Stuff (www.stuff.co.nz) \\
\hline $\begin{array}{l}\text { Link } \\
15\end{array}$ & $\begin{array}{l}\text { Blog post entitled "The } 10 \text { great } \\
\text { neoliberal myths of New } \\
\text { Zealand". }\end{array}$ & The Daily Blog (www.thedailyblog.co.nz) \\
\hline
\end{tabular}



explanatory potential of hyperlinks. Although not all the blogs studied use as many hyperlinks, they all use a certain number and show that the ideas they are defending are shared by others. Each statement in this text is backed by an external link. Another interesting feature from this point of view is the links found towards other blogs on the main page. This is a feature shared by many blogs and highlights the bonds between different bloggers. The two organisational blogs, however, don't make use of this feature. CJT has a resource section with hyperlinks to other blogs like Greenpeace New Zealand, Environmental Defense Society New Zealand, Kiwis Against Seabed Mining, US site on National Map of Fraccidents, US site on The Endocrine Disruption Exchange, for example. In the NPM, there is a long list of blogs in the section entitled "Blogs I follow" leading to other Maori blogs, one Samoan blog and other environmentalist ones. In M2E we also find a section of connected blogs, classified according to the author's interests, which are therefore clearly explicit. The first category of blogs he follows is Maori blogs, followed by that of "Indigenous Blogs" which again highlights the links established with other indigenous people beyond New Zealand. The third category is that of "Left Blogs" where we find, for example, FrogBlog, the Green Party of Aotearea New Zealand blog. The last category "Other blogs I Like" contains blogs on topics as varied as the Fluoridation of Water programs, in the blog entitled "The Open Parachute", or feminism, in a blog entitled "The Hand Mirror"10. The KB also has a section linking it to other blogs. If we look at the first five we notice that they are either blogs he follows because he has the same opinions, or blogs he follows because he is strongly opposed to their point of view and likes to contradict them.

The commentary section that appears in some blogs is another feature that characterises their interactivity. We note that there is no possibility for leaving comments on the TAG Oil blog. As for the CJT blog, it is possible to leave comments on the last posts but for most posts the comments option is deactivated. The comments that do appear on this blog are mostly comments from people who follow them and repost them on their own blogs. On the different posts where comments do appear, they are relatively few and we did not find any with more than ten comments. On the NPM the comment section is active, however there aren't very many (less than ten) and are mostly positive comments that show that the content of this blog is being reposted on to other blogs. On $\mathrm{KB}$, a very popular blog as we mentioned earlier on, the comment section is important and active. The last ten posts on this blog figure between 31 and 254 comments. This is a site for very heated debates between KB opponents and supporters. On M2E the comment section is activated but there are very few comments. The seventeen last posts figure 4 comments, all by the same person.

Technological progress also allows for the inclusion of media other than the written word in blog posts. The most obvious form is the inclusion of images. Not all the blogs resort to images. There are a large number on the TAG Oil blog, mostly of their plants and workers, all represented in a positive light. KB and M2E don't integrate images. NPM does, namely with images to show the effects of pollution, the most emblematic pictures being those of dead sea birds with their bellies full of plastic garbage. CJT also uses images to show the effects of pollution when it publishes a photo of a giant gas flare rising from a Todd energy well site on its $19^{\text {th }}$ June 2014 post. It also uses more enhanced forms of intermodality when it publishes an interactive map of New Zealand showing all the fossil fuel exploration and production sites. Another form of intermodality is to include video

ILCEA, 31 | 2018 
material in blogs. There is only one occurrence of a video in a post on the TAG Oil blog, a hyperlink entitled "Enriching New Zealand's future" published by PEPANZ presenting a 2:57 minute video, showing people working for the oil industry and expressing their views on it. The people selected to figure in this video are young, friendly and relaxed who explain with their simple words and strong local accents the various benefits of the industry.

Interactivity and intermodality are thus used in the blogs and can be seen as another defining characteristic of this discursive genre. However, as seen in the examples of the blogs selected for this study, the ways in which bloggers resort to these possibilities are varied, thus echoing another defining feature of blogs, their very personal nature.

\subsection{The Blog as a Place for Free and Highly Personal Speech}

31 As seen in the previous section, the different communicative features offered by blogs are used in different ways in the five blogs under consideration. This may be due to the fact that the selection was not based on generic criteria. In the corpus there are blogs that could be classified in different categories: organisational vs personal blogs, public affair $v s$ diary type blogs, blogs with a high number of followers vs blogs with very few followers. Despite this heterogeneity, there is a common feature between them: they present an openly personal point of view and testify to a strong degree of freedom of expression. According to bloggers, the personal aspect of the writing adds value, as it differentiates the blog post from what they consider the raw impersonal data found in mainstream journalism.

Naturally, this feature is probably more visible in the three personal blogs of the corpus than in the two organisational ones. Indeed, if we look at the use of the first person pronoun "I", the two organisational blogs have fewer occurrences. In the three personal blogs, the authors devote a section to presenting themselves. It is a way of bringing their discourse to life by linking it to their personal experience. Although David Farrar from the $\mathrm{KB}$ admits he employs people to work on his blog, he still presents it as reflecting personal opinions ${ }^{11}$. In M2E you also find elements of self-presentation that highlight the personal character of the content. The blogger who gives most details about herself is the author of NPM in her page entitled "the Deets on Me"12.

Another element that enhances the impression of a personal tone in the blogs studied here is the use of informal language. For instance in the KB, one finds incomplete sentences: "and not due to recessions either" (31/05/16), "can't have it both ways" (31/05/16). One also notices the use of irony that shows complicity with the reader: "I am sure Russel Norman would refuse to spend any money earnt from dirty oil!" (24/06/13). Finally, there are several instances of punning on the sonorities of fracking in the expressions such as, "fracking great news" (23/04/13) or "frack baby frack" (22/02/16). $\mathrm{M} 2 \mathrm{E}$ seems to enjoy the sonorities of fracking, as does $\mathrm{KB}$, when he uses the expression "frack off" (10/03/11) to indicate how he would welcome the fossil fuel industry. His use of informal or even vulgar language is frequent and even goes as far as an open invitation to violence (12/10/11). In the NPM there is no rude language but there are several marks of orality as in the following extract "So... tip of the month this month?? Has to go to the cuz Te Hamua Nikora who shared this pic with me on how to repurpose an old tshirt into a bag" (01/02/14). Although the use of informal language is toned down in the organisation blogs (TAG Oil, CJT), there are some exceptions. In the TAG Oil blog, the 
following sentence is a caption for an image of workers on the plants: "the guys hard at work" (01/11/10). It is significant that in the CJT blog also, there is an occurrence of rude language in the metatext. The photo of a Todd energy well gas flare published on $19^{\text {th }}$ June 2014 has the caption: "what the frack?", where we recognise the same play on words as in $\mathrm{KB}$ and M2E.

The freedom of expression embodied by the use of this informal tone is also presented by the bloggers as a great advantage. NPM explains her choice of the blog as a discursive genre because of this personal feature. She appreciates the fact that her writing is not edited in any way, as would have been the case in mainstream media (01/11/15). In another instance, she mentions the mainstream media as imposing brevity of messages which for her is not compatible with clarity and which she compensates for in her blog (07/08/16).

This positive vision of the unedited characteristic of blogs could, however, be counterbalanced if we consider that editing enables pre-publication feedback. It is often aimed at making the text clearer, more explicit, less controversial. As we have seen in the part on the narratives portrayed in the different blogs and in the section on informal language, moderation does not seem a quality that the bloggers aim for. In all the blogs considered, strong opinions concerning fossil fuel development are expressed, whether to criticise or to praise, as the radically different narrative structures we find in the different blogs testify. The use of hyperlinks is also interesting from this point of view. Although they do show a willingness on the part of the authors not to be seen as isolated in their views, the blogs and links chosen act as a filter as they lead only to content which confirms the author's point of view and leave out all the rest. Prior confirmed this feature of hyperlinks in his study of political blogs when he observed that "[w]hen political blogs link to other blogs, they mostly pick ideologically congenial ones" (2013: 104). This is enhanced by the fact that linking to other blogs is also a way of developing traffic on your own blog (Sullivan, 2008). According to Krishnamurthy who worked on comments and traffic in blogs, the most commented posts are either the most insightful or the most controversial (2002). Although the corpus includes blogs with different aims, different volumes of traffic and different perspectives, they can all be seen as defending a clearly partisan position on fossil fuel development. While giving general conclusions about the nature of blogs seems difficult on the basis of such a small sample, the impression given here is certainly not one of moderation.

\section{Conclusions}

This brief overview of blogs on fossil fuel development in New Zealand tends to confirm that it is difficult to propose stable generic features to define the blog. Rather than seeing it as a discursive genre, it can be seen as a discursive tool used for different generic purposes: "The blog, it seems clear now, is a technology, a medium, a constellation of affordances-and not a genre" (Miller \& Sheperd, 2004: 283). Just as blogs can't be clearly defined as a genre, they can't be defined as a story either, but rather as a non-linear meandering of thoughts that can potentially tell a story. In spite of this, blogs are a rich media that enable us to study narrative from a new angle. The chronologically simple structure of the blog doesn't prevent us from identifying a "plot" on fossil fuel development in each blog, if we consider several posts on the topic broadly. They adopt a distinct way of telling a story, as events unfold. With their interactivity, intermodality 
and openness, they seem a useful tool for anyone seeking to promote their political ideas. As fossil fuel development is a controversial issue in New Zealand today, blogs are an interesting medium to find out more about conflicting views held in the country. Although presented by their authors as an open media, questions of accessibility to their content remain. Usually, people start reading one of these blogs because it holds views they are interested in. From there, they may move on to other blogs with similar views, reinforcing a bubble effect whereby people tend to access only content which confirms ideas that they already hold. In this sense, blogs can be compared to other social media like Facebook or Twitter which received critical media coverage-especially after the United States election in 2016-for having contributed to a polarisation of political views. If blogs are described as a solution to countering the uniformity of thought experienced in mainstream media, it is mostly by theorists who are also bloggers. Though blogging is a form of public speech accessible to anyone, it is essentially a forum of exchange with likeminded people and a means of reassuring authors about the validity of their opinion. Blogging can become a hobby, and even a career, so it is not surprising that bloggers are willing to defend the value of blogs by opposing them to the mainstream media. Dialogue between rational views and use of moderate language certainly do not seem to be the main features of blogs as considered in this paper. Viewed in this light, maybe blogs, by giving counter-examples, are the best way of restating the benefits linked to edited publications, where an author revises and explains what he writes before publication, according to the recommendations of his editors. However, as an author aiming for publication in a peer-reviewed journal, whether I can comment objectively on this remains an open question.

\section{BIBLIOGRAPHY}

\section{Primary Sources}

TAG OIL BLOG: www.tagoil.com/media-center/tag-oil-blog

KIWI BLOG: www.kiwiblog.co.nz

Climate Justice TARAnaki Blog: www.climatejusticetaranaki.wordpress.com

THE NON Plastic MAORI: www.thenonplasticmaori.wordpress.com

MARS 2 EARTH BLOG: www.mars2earth.blogspot.fr

Secondary Sources

ADAM Jean-Michel (2011), Genres de récits - Narrativité et Généricité des Textes, Louvain-la-Neuve: Harmattan Academia.

BRYAN Alexander \& LEVINE Alan (2008), "Web 2.0. Storytelling: emergence of a new genre", EDUCAUSE Review, 43(6), <http://er.educause.edu/articles/2008/10/web-20-storytellingemergence-of-a-new-genre> (retrieved on 20/10/16). 
DUNLAP Thomas R. (1999), Nature and the English Diapora - Environment and History in the UnitedStates, Canada, Australia, and New Zealand, Cambridge: Cambridge University Press.

HASs Tanni (2005), "From Public Journalism to the Public's Journalism - Rhetoric and Reality on the Discourse on Weblogs", Journalism Studies, 6(3), 387-396.

HERRING Susan et al. (2004, January), "Bridging the Gap: A Genre Analysis of Weblogs", Proceedings of the Thirty-seventh Hawaii International Conference on System Sciences (HICSS-37), Los Alamitos: IEEE Press.

HOPKINS Jane \& MATHESON Donald (2005), "Blogging the New Zealand Election: The Impact of New Media Practices on The Old Game", Political Science, 57(2), 93-105.

KRISHNAMURTHY Sandeep (2002), “The Multidimensionality of Blog Conversations: The Virtual Enactment of September 11", Paper presented at the Internet Research 3.3, Maastricht, The Netherlands.

Loomis M. Terrence (2017), Petroleum Development and Environmental Conflict in Aotearoa New Zealand: Texas of the South Pacific, Lanham Maryland: Lexington Books.

MACDONALD Graeme (2013), "Research Note: The Resources of fiction", Reviews in Cultural Theory, 4 (2), 1-24.

MILLER Carolyn R. \& SHEPERD Dawn (2004), Blogging as Social Action: A Genre Analysis of the Weblog, retrieved from the University of Minnesota Digital Conservancy, <http:// hdl.handle.net/11299/172818>.

O'BRIEN Thomas (2013), "Fires and Flotillas: Opposition to Offshore Oil Exploration in New Zealand", Social Movement Studies, 12(2), 221-226.

O'BRIEN Thomas (2016), “Camping, climbing trees and marching to Parliament: spatial dimensions of environmental protest in New Zealand”, Kotuitui: New Zealand Journal of Social Sciences Online, 11 (1), 11-22.

PRIOR Markus (2013), “Media and Political Polarization”, Annual Review of Political Science, 16, 101-127.

REDDY Kotapati Srinivasa \& XIE En (2017), “Cross-border mergers and acquisitions by oil and gas multinational enterprises: Geography-based view of energy strategy", Renewable and Sustainable Energy Reviews, 72, 961-980.

REVAZ Françoise (2009), Introduction à la narratologie - Action et Narration, Bruxelles : De Boeck.

SUlLIVAN Andrew (2008), The Atlantic, November Issue, <https://www.theatlantic.com/magazine/ archive/2008/11/why-i-blog/307060/> (retrieved on 04/10/16).

WAITANGI TRIBUNAL (2011), Ko Aotearo Tenei : a report into claims concerning New Zealand law and policy affecting Maori culture and identity, Wellington: Legislation Direct.

\section{NOTES}

1. <https://www.nzpam.govt.nz/permits/petroleum/block-offer/> (retrieved on 27/01/17).

2. <http://www.tagoil.com/media-center/tag-oil-blog/> (retrieved on 12/11/16).

3. <https://climatejusticetaranaki.wordpress.com/> (retrieved on 10/09/16).

4. <https://thenonplasticmaori.wordpress.com/> (retrieved on 10/09/16).

5. <http://mars2earth.blogspot.fr/> (retrieved on 10/09/16). 
6. After this date there is an interruption of the blog. Although the writer took it up again in 2015, the focus of the blog changes and oil development is hardly mentioned.

7. Our translation.

8. An important figure in Polynesian mythology.

9. <https://openparachute.wordpress.com/>.

10. <http://thehandmirror.blogspot.fr/>.

11. <http://www.kiwiblog.co.nz/about/> (retrieved on 28/11/16).

12. $<$ https://thenonplasticmaori.wordpress.com/about/> (retrieved on $28 / 11 / 16$ ).

\section{ABSTRACTS}

This article explores the role of the narrative sequence in the debate over fossil fuel exploration and exploitation in New Zealand as it appears in a selection of blogs. Since 2008, the New Zealand government has sought to encourage the development of this industry, claiming the existence of many underexplored basins around the two islands. Perceptions on these prospects differ greatly as the blogs considered here exemplify. We first present the wider political, economic and cultural context leading to the production of the blogs, followed by a description of the different types of narrative sequences found in these blogs. We then go on to discuss the argumentative value of these blogs in the heated debate over resource exploitation. Finally, we draw some conclusions about the generic features of blogs.

Cet article explore le rôle de la séquence narrative dans le débat sur l'exploration et l'exploitation d'énergies fossiles, telles qu'elles apparaissent dans une sélection de blogs. Depuis 2008, le gouvernement néo-zélandais cherche à encourager le développement de cette industrie en affirmant l'existence de nombreuses réserves inexplorées autour des deux îles. Les points de vue sur ces perspectives de développement sont très variés, comme en témoignent les blogs présentés ici. Dans un premier temps, le contexte économique, politique et culturel ayant conduit à l'écriture de ces blogs est considéré. Puis, nous décrivons les différents types de séquences narratives qui y sont présentes. Nous analysons ensuite la valeur argumentative de ces blogs dans le débat musclé sur l'exploitation des ressources. Enfin, cette étude nous permet de conclure en présentant quelques caractéristiques génériques du blog.

\section{INDEX}

Mots-clés: blogs, énergies fossiles, séquence narrative, Nouvelle-Zélande, Maori

Keywords: blogs, fossil fuel, narrative sequence, New Zealand, Maori

\section{AUTHOR}

\section{CAMILLE BIROS}

Université Grenoble Alpes, ILCEA4 